\title{
Two Pressure Regulated Operons Common in the "Barophiles Branch"
}

\author{
L. Li, C. Kato, Y. Nogi and K. Horikoshi \\ The DEEP STAR group, Japan Marine Science and Technology Center, 2-15 Natsushima-cho, Yokosuka 237, JAPAN.
}

\begin{abstract}
DNA regions corresponding to portions of two different pressure-regulated operons previously identified in two deepsea barophilic bacteria were separately PCR amplified from a variety of deep-sea microorganisms and sequenced. With the two sets of primers employed, amplification was particularly successful from the more barophilic bacteria examined. $16 \mathrm{~S}$ rRNA sequence analysis revealed that these bacteria are all phylogenetically related and belong in a sub-branch of the genus Shewanella containing only the deep-sea Shewanella barophilic bacteria, which we define as the "Shewanella barophiles branch" containing at least two different species. Our results suggest that the DNA sequences of the pressure-regulated operons can be considered as marker sequences to identify the Shewanella barophilic strains.

[Barophilic bacteria, Deep-sea bacteria, High pressure adaptation, Pressure-regulation, Shewanella sp]
\end{abstract}

\section{Introduction}

Barophilic (also referred to as piezophilic) bacteria display elevated growth rates at pressures above 1 atmosphere $[1,2]$. We have isolated numerous barophilic bacteria from high pressure, low temperature deep-sea sediments and analyzed their growth characteristics [3-5].

In some instances these extremophiles have been found to modulate gene expression in response to pressure [6-10], presumably as part of an underlying sensory/adaptational mechanism for coping with the stress brought about by the change in their physical environment. For example, a pressureregulated operon which displayed expression positively controlled by high pressure, was cloned and characterized from the deep-sea barophilic bacterium strain DB6705 [7, 8] and the moderately barophilic bacterium strain DSS12 [9]. In both cases, the pressure-regulated operon was found to consist of two open reading frames (ORF1 and ORF2) of unknown physiological function $[8,11]$. Downstream from this operon, another pressure-regulated operon was discovered and its first ORF was designated ORF3 [9]. Based upon its deduced amino acid sequence and the results of heterologous complementation studies in Escherichia coli, ORF3 appears to encode the CydD protein [12]. In E. coli, CydD is required for the assembly of the cytochrome $b d$ complex, one of the components of the aerobic respiratory chain. E. coli cydD mutants display increased sensitivity to high pressure, but when bearing the DSS12 ORF3 gene on a plasmid these mutants display wildtype levels of high pressure sensitivity.

In order to understand the significance of ORFs $1-3$, it is important to determine their distribution in other shallow-water and deep-sea bacteria. In this paper, we document that sequences bearing homology to these ORFs are widely distributed in many deep-sea barophilic bacteria, but that this distribution is a reflection of the close phylogenetic relationships of the barophilic bacteria examined.

\section{Materials and Methods}

(1) Bacterial strains
A description of the bacteria used in this study is presented in Table 1.

Table 1. Bacterial strains used in this study

\begin{tabular}{llr}
\hline Bacterial strain & Properties (depth of isolate) & Ref. \\
\hline Barophilic bacteria & & \\
DB5501 & Opt. $50 \mathrm{MPa} / 10^{\circ} \mathrm{C}(2485 \mathrm{~m})$ & {$[5]$} \\
DB6101 & Opt. $50 \mathrm{MPa} / 10^{\circ} \mathrm{C}(5110 \mathrm{~m})$ & {$[5]$} \\
DB6705 & Opt. $50 \mathrm{MPa} / 10^{\circ} \mathrm{C}(6356 \mathrm{~m})$ & {$[5]$} \\
DB6906 & Opt. $50 \mathrm{MPa} / 10^{\circ} \mathrm{C}(6269 \mathrm{~m})$ & {$[5]$} \\
DB172F & Opt. $70 \mathrm{MPa} / 10^{\circ} \mathrm{C}(6499 \mathrm{~m})$ & {$[4]$} \\
PT99 & Opt. $69 \mathrm{MPa} / 9^{\circ} \mathrm{C}(8600 \mathrm{~m})$ & {$[13]$} \\
Moderately barophilic bacteria & \\
DSS12 & Opt. $30 \mathrm{MPa} / 8^{\circ} \mathrm{C}(5110 \mathrm{~m})$ & {$[5]$} \\
S. benthica & Opt. $30 \mathrm{MPa} / 4^{\circ} \mathrm{C}(4575 \mathrm{~m})$ & {$[14,15]$} \\
SC2A & Opt.20MPa $/ 20^{\circ} \mathrm{C}(1957 \mathrm{~m})$ & {$[16]$} \\
SS9 & Opt. $20 \mathrm{MPa} / 18^{\circ} \mathrm{C}(2551 \mathrm{~m})$ & {$[17]$} \\
DSJ4 & Opt. $10 \mathrm{MPa} / 10^{\circ} \mathrm{C}(5110 \mathrm{~m})$ & {$[5]$} \\
Barotolerant bacteria & & \\
DSK1 & Opt.0.1MPa $/ 10^{\circ} \mathrm{C}(6356 \mathrm{~m})$ & {$[5]$} \\
DSK25 & Opt.0.1MPa $/ 35^{\circ} \mathrm{C}(6500 \mathrm{~m})$ & {$[18]$} \\
S. hanedai & Opt. $0.1 \mathrm{MPa} / 14^{\circ} \mathrm{C}$ & {$[15,19]$} \\
Baro-sensitive bacteria & \\
E. coli & Opt.0.1MPa $/ 37^{\circ} \mathrm{C}$ & {$[20]$} \\
S. alga & Opt. $0.1 \mathrm{MPa} / 30^{\circ} \mathrm{C}$ & {$[15.21]$} \\
S. putrefaciens & Opt.0.1MPa $/ 26^{\circ} \mathrm{C}$ &
\end{tabular}

Barophilic bacteria are defined as those having an optimum growth pressure of more than $40 \mathrm{MPa}$. Moderately barophilic bacteria are defined as those having an optimal growth pressure of less than $40 \mathrm{MPa}$, and able to grow well at atmospheric pressure.

(2) PCR amplification and DNA sequencing

The isolation of the chromosomal DNA from these microorganisms and the PCR amplification were performed according to general methods [22]. PCR amplification of the genes of $16 \mathrm{~S}$ rRNA, ORF1 and 2 together, and part of ORF3 
was performed with a DNA Thermal Cycler model 9600 (Perkin-Elmer/Cetus Co. Norwalk, CT) using $50 \mu \mathrm{l}$ of PCR reaction mixture in each instance under the conditions recommended by the enzyme manufacturer (Takara Co. Otsu, Japan) according to the procedure reported previously [23]. The oligonucleotide primer sequences of ORF1.2 and ORF3 used in this study were described previously [23].

(3) DNA-DNA hybridization study

DNA-DNA hybridization was carried out at $40^{\circ} \mathrm{C}$ for $3 \mathrm{hr}$ and measured fluorometrically by using the method of Ezaki et al. [24]. The following type strains of reference species were used in the DNA-DNA hybridization: Shewanella putrefaciens, Shewanella hanedai IAM12641, Shewanella benthica ATCC43992.

\section{Results}

(1) Phylogenetic relationships of deep-sea bacteria

The phylogenetic relationships among these bacteria based upon 16S rRNA sequence determination are shown in Fig. 1. All of the strictly barophilic strains (DB5501, DB6101, DB6705, DB6906, DB172F, and Shewanella sp. PT99) and some of the moderately barophilic strains (DSS12 and $S$. benthica) group together in the same sub-branch of the genus Shewanella, defined here as the "Shewanella barophiles branch". Other moderately barophilic strains (Shewanella sp. SC2A, Photobacterium sp. SS9 and DSJ4) and barotolerant strains ( $S$. hanedai and DSK1) are widely distributed within the Proteobacteria $\gamma$-subgroup, but outside of the barophiles branch, and the Gram positive barotolerant strain DSK25 falls into the genus Bacillus. It is striking that all of the strictly barophilic microbes which we have analyzed group within a particular branch of a single genus. The preponderance of Shewanella within several different barophile collections is likely to be a reflection of the selective advantage these microbes possess over other deep-sea barophiles under the nutrient-rich culturing conditions employed, as a result of their known respiratory versatility [25].

\section{(2) PCR amplification of pressure-regulated operons}

The results of PCR amplification are shown in Fig. 2. The results indicate that with the primers employed for ORF1.2 and ORF3 amplification was possible for all of the strictly barophilic strains (DB5501, DB6101, DB6705, DB6906, DB172F, and $S$. sp. PT99) and some of the moderately barophilic strains (DSS12 and $S$. benthica), but not for the other Shewanella strains (S. hanedai, S. alga, S. putrefaciens, and $S$. sp. SC2A), the other deep-sea bacterial strains (Photobacterium sp. SS9 and DSJ4, DSK1, and DSK25), or E. coli. All of the strains which yielded positive PCR results belong in the Shewanella barophiles branch (Fig. 1). Thus, the ability to amplify ORF 1.2 and ORF3 by PCR from certain deep-sea bacterial strains appears to reflect the close taxonomic relationships of these bacteria to DB6705 and DSS12.

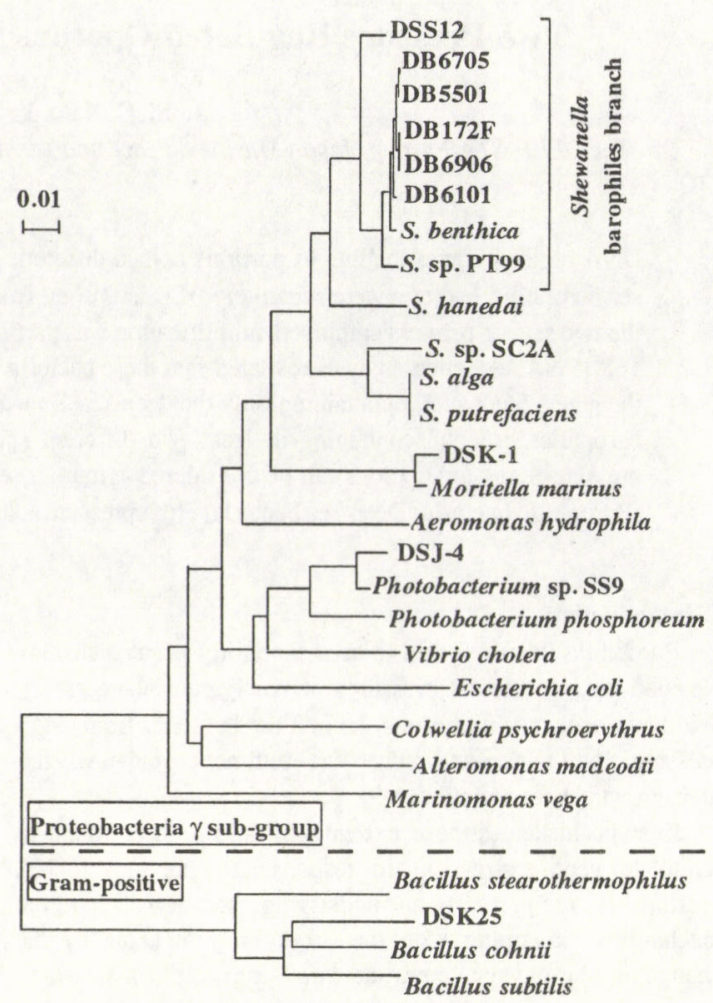

Fig. 1. Phylogenetic tree showing the relationship of $16 \mathrm{~S}$ rDNA within the Proteobacterium $\gamma$-subgroup and genus Bacillus using the neighbor-joining method [26].

A.
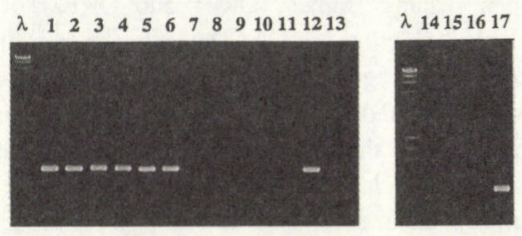

B.

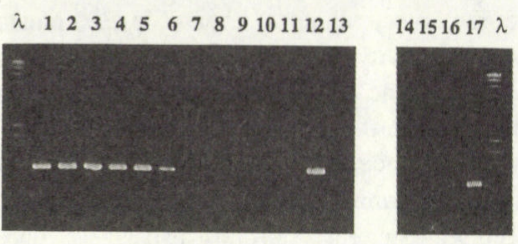

Fig. 2. Gel electrophoresis of PCR products amplified with the ORF1.2 primers (A) and the ORF3 primers (B). Lane 1, molecular size markers (HindIII-digested $\lambda$ DNA); lanes 1; DB5501, 2; DB6101, 3; DB6705, 4; DB6906, 5; DB172F, 6; DSS12, 7; DSK1, 8; DSJ4, 9; DSK25, 10; Photobacterium sp. SS9, 11; S.. sp. SC2A, 12; S.. sp. PT99, 13; E. coli, 14; S. alga, 15; $S$. putrefaciens, $16 ; S$. hanedai, 17; $S$. benthica. 
(3) DNA-DNA hybridization

The results of DNA-DNA hybridization analysis comparing the Shewanella standard strains and the barophilic strains belonging to the Shewanella barophiles branch are shown in Table 2. The DNAs of the strictly barophilic strains DB5501, DB6101, DB6705, DB6906, DB172F and PT99 were highly homologous to the DNA of $S$. benthica (more than $80 \%$ ), and the homology \% between strain DSS12 and these strains was significantly lower (30-40\%). Therefore, the above barophilic strains except for strain DSS12 should be classified as members of the same species, i.e. S. benthica, and strain DSS12 should be classified as another species closely related to them.

Table 2. DNA-DNA hybridization between the genus Shewanella and deep-sea barophilic Shewanella strains.

\begin{tabular}{lccccc}
\hline \multirow{2}{*}{ Strain } & \multicolumn{5}{c}{ Hybridization ratio (\%) of the DNA of } \\
\cline { 2 - 5 } & S.put & S. han & S. ben & DB6705 & DSS12 \\
\hline S. putrefaciens & 100 & 1 & 8 & 9 & 13 \\
S. hanedai & 7 & 100 & 8 & 10 & 15 \\
S. benthica & 7 & 15 & 100 & 82 & 41 \\
DB6705 & 12 & 29 & 81 & 100 & 36 \\
DSS12 & 13 & 12 & 31 & 39 & 100 \\
DB172F & 9 & 14 & 86 & 95 & 39 \\
DB5501 & 9 & 9 & 99 & 103 & 35 \\
DB6101 & 10 & 12 & 87 & 99 & 34 \\
DB6906 & 10 & 11 & 83 & 95 & 37 \\
PT99 & 12 & 16 & 82 & 102 & 46 \\
\hline
\end{tabular}

\section{Discussion}

The high-pressure-adapted barophilic bacteria isolated from the deep-sea are widely distributed as members of the genera Colwellia, Photobacterium, Moritella and Shewanella in the Proteobacteria $\gamma$-subgroup in the phylogenetic tree based on $16 S$ rRNA sequences [27]. But still no particular DNA sequence has been found to define the barophilic strains. As we report in this paper, the DNA sequences of pressure-regulated operons identified in previous studies are distinctive of deepsea barophilic Shewanella. Therefore, we may be able to use these sequences as markers to identify strains belonging the Shewanella barophiles branch. In fact, we have reported that the sequences of these pressure-regulated operons were found in DNA from marine sediment obtained from the world'd deepest ocean trench, the Mariana Trench Challenger Deep, at a depth of about $11,000 \mathrm{~m}$ [23].

In conclusion, the pressure-regulated genes designated ORFs 1-3 previously identified in two barophilic bacterial isolates, have been found to be distributed among strictly and moderately barophilic bacteria, all of which are grouped in a particular sub-branch of the genus Shewanella, defined as the "Shewanella barophiles branch". Thus, the distribution of these genes and their high sequence similarity correlates with phylogenetic position. Additional experiments will be required to address the role of these genes in barophily.

\section{References}

[1] C. E. Zobell, R. Y. Morita, J. Bacteriol., 73, 563 (1957).

[2] A. A. Yayanos, Annu. Rev. Microbiol., 49, 777 (1995).

[3] C. Kato, A. Inoue, K. Horikoshi, Trends in Biotechnol., 14, 6 (1996).

[4]C. Kato, N. Masui,K. Horikoshi, J. Mar. Biotechnol., 4, 96 (1996).

[5] C. Kato, T. Sato, K. Horikoshi, Biodiv. Conserv. , 4, 1 (1995).

[6] D. Bartlett, M. Wright, A. A. Yayanos, M. Silverman, Nature, 342, 572 (1989).

[7] C. Kato, M. Smorawinska, T. Sato, K. Horikoshi, J. Mar. Biotechnol., 2, 125 (1995).

[8] C. Kato, M. Smorawinska, T. Sato, K. Horikoshi, Biosci. Biotech. Biochem., 60, 166 (1996).

[9] C. Kato, A. Ikegami, M. Smorawinska, R. Usami, K. Horikoshi, J. Mar. Biotechnol., (1977) in press.

[10] T. J. Welch, D. H. Bartlett, J. Bacteriol., 178, 5027 (1996). [11] D. H. Bartlett, C. Kato, K. Horikoshi, Res. Microbiol., 146, 697 (1995).

[12] C. Kato, H. Tamegai, A. Ikegami, R. Usami, K. Horikoshi, J. Biochem., 120, 301 (1996).

[13] E. F. DeLong, A. A. Yayanos, Appl. Environ. Microbiol., 51, 730 (1986).

[14] J. W. Deming, H. Hada, R. R. Colwell, K. R. Luehrsen, G. E. Fox, J. Gen. Microbiol., 130, 1911 (1984).

[15] M. T. MacDonell, R. R. Colwell, Appl. Microbiol., 6, 171 (1985).

[16] A. A. Yayanos, A. S. Dietz, R. Van Boxtel, Appl. Environ. Microbiol., 44, 1356 (1982).

[17] E. F. DeLong, Adaptations of deep-sea bacteria to the abyssal environment. $\mathrm{Ph}$. D. thesis. University of California, San Diego. San Diego, Calif. (1986).

[18] C. Kato, S. Suzuki, S. Hata, T. Ito, K. Horikoshi, JAMSTECR., 32, 7 (1995).

[19] M. J. Jensen, B. M. Tebo, P. Baumann, M. Mandel, K. H. Nealson, Curr. Microbiol., 3, 311 (1980).

[20] R. A. Rossello-Mora, et al., System. Appl. Microbiol., 17, 569 (1994).

[21] R. Owen, R. M. Legros, S. P. Lapage, J. Gen. Microbiol., 104, 127 (1978).

[22] J. Sambrook, E. F. Fritsch, T. Maniatis, Molecular cloning: a laboratory manual, 2nd ed. Cold Spring Harbor Laboratory, Cold Spring Harbor, N. Y. (1989).

[23] C. Kato, L. Li, J. Tamaoka, K. Horikoshi, Extremophiles, 1, (1997) in press.

[24] T. Ezaki, Y. Hashimoto, E. Yabuuchi, Int. J. Syst. Bacteriol., 39, 224 (1989).

[25] D. A. Saffarini, K. H. Nealson, J. Bacteriol., 175, 7938 (1993).

[26] N. Saitou, M. Nei, Mol. Biol. Evol., 4, 406 (1987).

[27] E. F. DeLong, D. G. Franks, A. A. Yayanos, Appl. Environ. Microbiol., 63, 2105 (1997). 